\title{
A study on animal welfare standards in traditional sheep breeding enterprises"
}

\author{
İbrahim KILIÇ ${ }^{1}$, Zehra BOZKURT ${ }^{2}$, Mustafa TEKERLİ ${ }^{2}$, Serdar KOÇAK ${ }^{2}$, \\ Koray ÇELIKELOĞLU ${ }^{2}$
}

\begin{abstract}
${ }^{1}$ Afyon Kocatepe University, Faculty of Veterinary Medicine, Department of Biostatistics; ${ }^{2}$ Afyon Kocatepe University, Faculty of Veterinary Medicine, Department of Animal Husbandry, Afyonkarahisar, Turkey.
\end{abstract}

\begin{abstract}
Summary: The purpose of this study was to evaluate the factors affecting animal welfare such as housing, care and administration and some technical breeding applications in traditional sheep breeding enterprises in terms of animal welfare standards. After the generation of qualitative and quantitative variables an observation form was developed for the collection of data pertaining to the welfare standards of 100 sheep breeding enterprises in 19 villages of Şuhut, Emirdağ, Çay and Sultandağ towns of Afyonkarahisar province. Accordingly, it was determined that the average living area per sheep was $0.76 \mathrm{~m}^{2}$. The average temperature in the enterprises was detected as $21.06^{\circ} \mathrm{C}$ while the average moisture was calculated as $43.20 \%$. Additionally, it was detected that the average birth rate per enterprise was $79.25 \%$. Moreover, it was identified that no health control was conducted in $20 \%$ of the enterprises. It was also discovered that the average number of employees per enterprise was 4.57 person. In addition to this, it was determined that the employees of the enterprises had had no prior training on animal welfare.

Key words: Animal welfare, traditional sheep breeding, welfare standards
\end{abstract}

\section{Geleneksel yetiştiricilik yapılan koyunculuk işletmelerinde hayvan refahı standartları üzerine bir araştırma}

Özet: Bu araştırmanın amacı, geleneksel yetiştiricilik yapılan koyunculuk işletmelerinde hayvan refahını etkileyen barındırma, bakım ve idare ile bazı pratik yetiştirme işlemlerinin refah standartları yönünden değerlendirilmesidir. Refah standartlarına ilişkin verilerin toplanması için nicel ve nitel değişkenlerden oluşan gözlem formu geliştirilmiş ve Afyonkarahisar iline bağlı Şuhut, Emirdağ, Çay ve Sultandağ i ilçelerindeki 19 köyde faaliyet gösteren toplam 100 koyunculuk işletmesinde uygulama gerçekleştirilmiştir. Buna göre, koyun başına ortalama alan $0.76 \mathrm{~m}^{2}$ belirlenmiştir. İşletmelerdeki ortalama sicaklık $21.06{ }^{\circ} \mathrm{C}$ ve ortalama nem \%43.20 olarak tespit edilmiştir. Diğer taraftan, işletme başına ortalama doğum oranının \%79.25 olduğu ve işletmelerin \%20'sinde herhangi bir sağlık kontrolü yapılmadığı saptanmıştır. Ayrıca, ortalama çalışan sayısının işletme başına 4.57 kişi olduğu ve hayvan refahına ilişkin daha önce herhangi bir eğitim almadıkları belirlenmiştir.

Anahtar sözcükler: Geleneksel koyun yetiştiriciliği, hayvan refahı, refah standartları

\section{Introduction}

Since the grazing sheep are able to display inherent behavior and meet their physiological needs on the pastureland the welfare status of sheep has been considered to be good. However, being exposed to harsh environmental conditions, stress caused by insufficient nourishment and water on the pastureland, unfavorable weather conditions, lameness and parasitic diseases are major factors which decrease the welfare of sheep (22).

In extensive breeding sheep, once the quality and amount of the feed plants of the pasture decrease the animals become stressed and as a result various diseases may incur. Coarse feed insufficiency has a negative impact on milk yield and fertility due to decrease in rumen fermentation and protein synthesis as well as welfare $(12,22)$. Other significant factors which have an impact on the welfare and performance of sheep are the structural characteristics of the pasture, features such as height of plants, root leaf ratio and plant intensity which are crucial for the intake of forage $(15,21)$. In addition, the use of natural pastures increases endoparasitic diseases and thus has a negative impact on the feed conversion, live weight, milk-fleece yield and reproductive performance of sheep (18). On the other hand lameness and numbering methods used in sheep breeding are the other important challenges in extensive systems. For this reason it is mandatory that a regular and adequate veterinary action plan with health protection plans for

\footnotetext{
* This study receiver the support of Afyon Kocatepe University Scientific Research Projects Coordination Unit with Project number 10.VF.04.
} 
sheep herds and the treatment of sick sheep is prepared and applied $(13,25)$.

The conditions of the shelters are significant in terms of assessing welfare and productivity in sheep breeding. The area designated per animal in the shelter, bedding and feces administration and climatic factors within the shelter (temperature, humidity and air quality) must be appropriate and monitored carefully (22). A study carried out by Sevi et al (23) revealed that the intensity of airborne micro-organisms and coliform bacteria increased when the area allocated per animal in the shelter decreased and this in turn was reflected as a negative impact on yields. For this reason it is very important for animal welfare and protection of yield performance that sufficient space is allocated for the animals in a shelter and bedding is managed properly. It is also reported that issues such as internal pen arrangements, ventilation, lighting, excessive sunlight, facilitated pasture access, interaction between shepherd and animals, milking conditions, hygiene and noise have an impact on the welfare and health of sheep $(9,24)$.

The purpose of this study was to assess the impact of housing, care and management as well as some practical breeding procedures applied by traditional breeding establishments in Turkey in terms of welfare standards.

Table 1. The findings on conditions of housing, ventilation, feeding and personnel.

Tablo 1. Barındırma, havalandırma, besleme ve personel koşullarına ilişkin bulgular.

\begin{tabular}{|c|c|c|}
\hline Dimensions & Variables & Findings \\
\hline \multirow[t]{10}{*}{ Housing } & The average number of sheep per enterprise (head) & 198.15 \\
\hline & The average ground area per enterprise $\left(\mathrm{m}^{2}\right)$ & 151.10 \\
\hline & The average volume per enterprise $\left(\mathrm{m}^{3}\right)$ & 443.04 \\
\hline & The average volume per sheep $\left(\mathrm{m}^{3}\right)$ & 2.24 \\
\hline & The average area per sheep $\left(\mathrm{m}^{2}\right)$ & 0.76 \\
\hline & The average window area per enterprise $\left(\mathrm{m}^{2}\right)$ & 2.30 \\
\hline & The average door width per enterprise (m) & 1.39 \\
\hline & The average flue area per enterprise $\left(\mathrm{m}^{2}\right)$ & 0.83 \\
\hline & Partitioning & available $(\% 26)$; unavailable $(\% 74)$ \\
\hline & Lighting & $\begin{array}{l}\text { fluorescence }(\% 50) \text {; tungsten }(\% 35) \\
\text { fluorescence }+ \text { tungsten }(\% 15)\end{array}$ \\
\hline \multirow{6}{*}{$\begin{array}{l}\text { Air } \\
\text { conditioning } \\
\text { and ventilation } \\
\text { indoors }\end{array}$} & The average temperature per enterprise $\left({ }^{\circ} \mathrm{C}\right)$ & 21.06 \\
\hline & The average humidity per enterprise (\%) & 43.20 \\
\hline & The average carbon dioxide per enterprise (ppm) & 1556.40 \\
\hline & The average oxygen per enterprise (ppm) & 20.47 \\
\hline & The average ammonia per enterprise (ppm) & 58.05 \\
\hline & Insulation material & $\begin{array}{l}\text { roof }[\operatorname{tiles}(\% 65), \text { wattles }(\% 30), \text { wood }(\% 5)] \\
\text { wall }[\text { stone }(\% 35), \text { briquette }(\% 30) \text {, brick }(\% 20) \text {, } \\
\text { concrete }(\% 10) \text {, adobe }(\% 5)] ; \\
\text { ground }[\operatorname{concrete}(\% 70), \text { soil }(\% 30)]\end{array}$ \\
\hline \multirow{10}{*}{$\begin{array}{l}\text { Feeding and } \\
\text { pasture } \\
\text { management }\end{array}$} & The general structure of the ground & stony \\
\hline & Porch status in the pasture & no \\
\hline & Pasture and water source distance $(\mathrm{km})$ & 1.40 \\
\hline & Check-out time for pasture & $07: 50$ \\
\hline & Pasture rotation time & $19: 25$ \\
\hline & The general flora of pastures & $\begin{array}{l}\text { meadow grass, clover, gramineae, vetch weeds, } \\
\text { smartweed, astragalus, thyme }\end{array}$ \\
\hline & Feed concentrate & own $(\% 25)$; buy $(\% 60)$; own+ buy $(\% 15)$ \\
\hline & Roughage & own (\%90); buy $(\% 10)$ \\
\hline & Licking blocks & available $(\% 70)$; unavailable $(\% 30)$ \\
\hline & Flushing & available $(\% 5)$; unavailable $(\% 95)$ \\
\hline \multirow[t]{6}{*}{ Personnel } & The average number of personnel per enterprise & 4.57 person \\
\hline & The average educational level of personnel & 6.10 year \\
\hline & Social security of personnel & yes $(\% 77)$; no $(\% 23)$ \\
\hline & Training in terms of animal health of personnel & yes $(\% 8)$; no $(\% 92)$ \\
\hline & Training in terms of animal welfare of personnel & yes $(\% 0)$; no $(\% 100)$ \\
\hline & Named their sheep & yes $(\% 65) ;$ no $(\% 35)$ \\
\hline
\end{tabular}




\section{Materials and Methods}

The observation form developed for the study contained qualitative and quantitative variables for factors consisting of housing, air conditioning and ventilation, feeding and pasture management, personnel status, yields and controls, modifications, herd health and health protection, milk and milking, shearing and fleece status and the presence of dogs. The sample size was calculated with the formula $\left(n=P Q Z_{\alpha}^{2} / d^{2}\right) . \quad \mathrm{P}=0.5$, $\mathrm{Q}=0.5$, effect size $\mathrm{d}=0.1$ and $\mathrm{Z}_{0.05}=1.96$ (for significance level $\alpha=0.05$ ) were used as parameters in the formula, and minimum sample size was calculated as 97 enterprises through the formula. Accordingly, the multiphase sampling method was taken advantage of together with stratified and cluster sampling methods and applied to a total of 100 sheep enterprises between the months of March-June raising Prrlak sheep in 19 villages in the districts of Şuhut, Emirdağ, Çay and Sultandağ 1 of Afyonkarahisar province which hosts the largest share in red meat production in Turkey. The housings were measured for gas in the mornings at 05.30-6.30 hours with a digital BW GasAlertMicro 5 IR brand gas measurement device.

It was endeavored to reveal the present animal welfare status by taking advantage of SPSS 14.01 for Windows and Microsoft Excel 2007 programs to analyze the determinations, measurements and observations obtained on site as well as descriptive statistical methods.

\section{Results}

The descriptive values pertaining to sheep enterprises examined in this study have been presented in Tables 1 and 2. According to Table 1 the average number of sheep per enterprise and the average area allocated per sheep were 198.15 and $0.76 \mathrm{~m}^{2}$ respectively. The average temperature per housing was determined as $21.06{ }^{\circ} \mathrm{C}$ with a humidity of $\% 43.20 \%$ while the amount of carbon dioxide was determined as $1556.40 \mathrm{ppm}$, oxygen as $20.27 \mathrm{ppm}$ and amount of ammonia to be $58.05 \mathrm{ppm}$. An examination of the feeding and pasture management conditions revealed that the general structure of the ground was stony and the general flora consisted mainly of meadow grass, clover, graminae and vetch weeds. $60 \%$ of the enterprises used factory feed as feed concentrate while $90 \%$ manufactured their own coarse feed, $70 \%$ had licking blocks and $95 \%$ of the enterprises had no conscious flushing (washing) facilities. The average 4.57 were employed per enterprise while the average educational level of personnel was 6.1 years. It was determined that none had received training in terms of animal welfare.

According to Table 2 on average 12.9 sheep per herd were sorted due to age, disease or culling, while the average fertility rate was $79.25 \%$. Weighing was reported by $75 \%$ of the enterprises, $40 \%$ reported milking and all reported shearing. An examination of the modifications revealed that $90 \%$ of the enterprises did not cut ears, $95 \%$ did not cut tails nor did $90 \%$ of the enterprises dehorn their animals. Findings pertaining to herd health showed that $20 \%$ of the enterprises did not carry out any form of health checks and $85 \%$ of the farmers reported mastitis in their herds. The $30 \%$ of the enterprises inspected in this study had earthen floors. The pens were cleaned once or twice per year and this cleaning took place only when the herd went to pasture and consisted of removing the manure and bedding which had accumulated all winter and scattering lime onto the ground afterwards. It is understood that no herd health plan or program is applied by the enterprises. Combating parasites is carried out with methods involving tablets and bathing. Although vaccination was applied to all the herds (brucella, foot and mouth disease, pox, PPR, enterotoxemia, combination vaccines) particularly enterotoxemia, pseudotuberculosis, foot and mouth disease, listeriosis or Coenurose and foot ailments were observed. Almost all of the animals of the studied enterprises were treated by veterinary surgeons. The enterprises mostly presented their milk in the form of milk, cheese and yoghurt and $45 \%$ of the products were consumed within the household. The fleece of the sheep was usually shorn in June and July with manual shears (clips) and 65\% of the fleece was exploited commercially. In addition the number of dogs per enterprise was 2.3 on average and $85 \%$ of the dogs were male.

\section{Discussion and Conclusion}

This study was carried out in sheep breeding enterprises which are wholly dependent on grazing in Afyonkarahisar province in terms of animal welfare standards. The sheep are mostly kept in closed pens during December-March and taken to pasture during April and November. Although some enterprises which have an airing area may allow the sheep to go outdoors when there is minimal rainfall during the 4 month period when the sheep are kept in closed quarters the sheep are mostly kept indoors particularly during the 2-3 month period when winter conditions prevail.

As a result of this study the average number of sheep (198.15 sheep/enterprise) reveals that most of the enterprises are medium and small family enterprises. The closed shelter area per sheep per enterprise has been calculated as $0.76 \mathrm{~m}^{2} / \mathrm{sheep}$. According to this value the live weight of pirlak sheep (40-50 $\mathrm{kg}$ average live weight) is less than the values for the area allocation per live weight for similar sheep reported by international organizations such as IPARD (3) $\left(0.7-1.80 \mathrm{~m}^{2} / \mathrm{sheep}\right)$, RSPCA (6) (1.65-1.80 m²/sheep), DEFRA (2) (1.0-1.4 $\mathrm{m}^{2} /$ sheep) and PIMC (5) (0.9-1.3 $\mathrm{m}^{2} /$ sheep). This situation gives rise to the thought that there is a negative impact on the welfare of the sheep particularly during the 
Table 2. The findings on yields, modifications, herd health, milking, shearing and status of shepherd dog. Tablo 2. Verim, modifikasyonlar, sürü sağlığı, sağım, kırkım ve sürüde köpek durumuna ilişkin bulgular.

\begin{tabular}{|c|c|c|}
\hline Dimensions & Variables & Findings \\
\hline \multirow{18}{*}{$\begin{array}{l}\text { Yields and } \\
\text { controls }\end{array}$} & Pregnancy ratio (\%) & 85.48 \\
\hline & Birth ratio $(\%)$ & 79.25 \\
\hline & Fertility ratio $(\%)$ & 14.52 \\
\hline & Lamb yield (\%) & 99.49 \\
\hline & Abortion ratio $(\%)$ & 7.37 \\
\hline & The average number of lambs per birth & 1.26 \\
\hline & Single birth rate $(\%)$ & 73.16 \\
\hline & Twin birth rate $(\%)$ & 24.62 \\
\hline & Multiple birth rate $(\%)$ & 26.84 \\
\hline & Difficult birth ratio (\%) & 1.43 \\
\hline & Average time of weaning (mouth) & 4.16 \\
\hline & Number of sorted sheep per herd & 12.9 \\
\hline & The reasons for the sorting & age, disease, culling \\
\hline & The average fattening period (mouth) & 2.97 \\
\hline & The average number of fattening lambs & 57.67 \\
\hline & Measuring the live weight & yes $(\% 75)$; no $(\% 25)$ \\
\hline & Milking status & yes $(\% 40)$; no $(\% 60)$ \\
\hline & Shearing status & yes $(\% 100) ;$ no $(\% 0)$ \\
\hline \multirow[t]{3}{*}{ Modifications } & Ear cutting & yes $(\% 10) ;$ no $(\% 90)$ \\
\hline & Tail cutting & yes $(\% 5)$; no $(\% 95)$ \\
\hline & Dehorning & yes $(\% 10)$; no $(\% 90)$ \\
\hline \multirow{10}{*}{$\begin{array}{l}\text { Herd health and } \\
\text { health } \\
\text { protection }\end{array}$} & Periodic animal health controls & yes $(\% 80) ;$ no $(\% 20)$ \\
\hline & The most common diseases & $\begin{array}{l}\text { enterotoxemia, pseudotuberculosis, foot and mouth } \\
\text { disease, listeriosis or coenurose }\end{array}$ \\
\hline & The most common precaution for mouth disease & antibiotics, lime \\
\hline & The general method of shelter cleaning & removing the bedding in ground \\
\hline & The frequency of shelter cleaning & once or twice per year \\
\hline & $\begin{array}{l}\text { The average distance between enterprises and } \\
\text { some units }\end{array}$ & $\begin{array}{l}\text { water source }(450 \mathrm{~m}) \text {; pasture }(1.20 \mathrm{~km}) \text {; village }(3.50 \\
\mathrm{km}) \text {; town }(7.50 \mathrm{~km})\end{array}$ \\
\hline & Presence of mastitis & yes $(\% 85)$; no $(\% 15)$ \\
\hline & Presence of sheep bath & available (\%95); unavailable $(\% 5)$ \\
\hline & Vaccination applications & yes $(\% 100) ;$ no $(\% 0)$ \\
\hline & Vitamin applications & yes $(\% 85) ;$ no $(\% 15)$ \\
\hline \multirow{7}{*}{$\begin{array}{l}\text { Milk and } \\
\text { milking }\end{array}$} & The general use of milk & milk, cheese, yogurt \\
\hline & Ferment feature & commercial culture \\
\hline & Milking type & manually \\
\hline & The average age of the milking person & 43.13 \\
\hline & The average education of the milking person & 5.00 years \\
\hline & The average experience of the milking person & 24.36 years \\
\hline & Consuming or marketing of milk & Home consume $(\% 45)$; marketing $(\% 55)$ \\
\hline \multirow{7}{*}{$\begin{array}{l}\text { Shearing and } \\
\text { fleece status }\end{array}$} & General shearing time & June, July \\
\hline & The frequency of shearing & once per year \\
\hline & Scissors type & manual \\
\hline & The average age of the shearing person & 5.73 \\
\hline & The average education of the shearing person & 5.06 years \\
\hline & The average experience of the shearing person & 20.56 years \\
\hline & Evaluation of wool-fleece- & own $(\% 35)$; marketing $(\% 65)$ \\
\hline \multirow{2}{*}{$\begin{array}{l}\text { Presence of } \\
\text { shepherd dogs }\end{array}$} & The average number of dogs per enterprise & 2.3 \\
\hline & Gender of dogs & male $(\% 85) ;$ female $(\% 15)$ \\
\hline
\end{tabular}


winter. Similarly, there are studies which claim that inadequate housing conditions lead to low yield, suppression of the immune system and diseases in sheep $(9,22)$.

The study revealed that most of the sheep enterprises had separate pens for lambs, rams and ewes, however no separate pens were available for yearling lambs, pregnant and lambing ewes as well as sick animals. This situation can cause problems among the animals and a decrease their welfare status. Indeed, risks regarding different physiological, behavioral and social needs for sheep of different ages, gender and physiological status and sick and pregnant sheep being under chronic social stress from other sheep in the social hierarchy have been reported $(2,3,6,13)$.

The areas for the floors, windows and flues of the closed pens have been calculated as $151.10 \mathrm{~m}^{2}, 2.30 \mathrm{~m}^{2}$ and $0.83 \mathrm{~m}^{2}$ respectively. The ideal window area has been reported as $1 / 10-1 / 20$ of the floor area while the ideal flue opening should be between $1 / 100$ and $2 / 100$ (3). According to the floor area average calculated for this study the ideal window area should be $7.55-15.11 \mathrm{~m}^{2}$ while the flue opening should be between 1.51-3.02 $\mathrm{m}^{2}$. In addition, the average door width $(1.39 \mathrm{~m})$ is considerably under the figure provided by IPARD (3) welfare standards $(2.4 \mathrm{~m})$. The fact that the window and flue areas of the investigated enterprises are below the ideal values indicate that the air quality is poor. Indeed the ammonia amount in the air of the studied pen was $58.05 \mathrm{ppm}$ which is way over the optimum welfare criteria values defined by organizations such as IPARD (3) (20-30 ppm) and RSPCA (6) (<20-30 ppm). Similarly the carbon dioxide level was found to be relatively high. According to these results the air quality of the closed pens of the studied enterprises was poor and this situation is assessed as a risk which could compromise the welfare of the sheep. In addition, a comparison of the pen's internal temperatures and humidity values with the optimum values for sheep (5-25 $\left.{ }^{\circ} \mathrm{C}\right)(\% 50-70)$ respectively shows that the temperature was at the top level $\left(21.06{ }^{\circ} \mathrm{C}\right)$ while the relative humidity value $(\% 43)$ was low $(3,11,22)$.

Ventilation is an important feature in maintaining farm animal welfare and the sustainability of their productivity by ensuring heat exchange between the body surface of the animal and its perimeter, in ensuring optimum air quality and the removal of various contaminants and harmful gases from the pen. Indeed, Sevi et al (22) report that housing conditions have an enormous impact on the welfare of sheep, particularly waste management and micro-climatic factors (temperature, relative humidity and airborne gases) need to be monitored carefully. Clark and McArthur (11) reported that the thermal environment inside the housing had an effect on animal yields, health and welfare which was why poor housing design and inappropriate microclimate caused thermal stress and compromised welfare. Caroprese (9) indicated that housing design increased the microclimate stress risk and that poor housing conditions caused health problems, mainly mastitis and that there was a significant relationship between such health losses and welfare losses.

According to these results the window and flue openings were inadequate and as the housing density was high and air conditioning inside the housing was poor it can be said that particularly closed housing carries a risk of inadequate ventilation. This situation appears to be supported by the frequency of mastitis $(85 \%)$ and the prevalence of foot and respiratory system diseases in the studied enterprises. Indeed the studies carried out by Caroprese et al (8) and Sevi et al (23) emphasized the importance of internal air quality of the housing and reported that dense housing increased the intensity of airborne micro-organisms.

It was determined that in general windows were used to ensure lighting in the closed pens of the studied enterprises during the day while artificial lighting was used at night. The most common form of artificial lighting used by the enterprises was with either fluorescent or tungsten bulbs. It can be concluded that the minimal window area in these enterprises carried a risk in obtaining natural daylight for the animals inside the housing. The risk is supported by the fact that it has been reported that the intensity and color of the light inside the housing affects animal welfare (9), particularly light intensity can change the behaviour and feed intake of sheep (10), cause abnormal behaviour (24) and sheep receiving inadequate daylight show a proliferation of lymphocytes with a negative impact on welfare (1).

The study indicated that the sheep spend the summer season exclusively grazing on a pasture (consisting mainly of plants such as prairie grass, clover, graminae, vetch weed, knotweed, blessed thistle, mountain sage, milk vetch and thyme) which is shared by more than one herd for approximately 8 months between April-November. For this reason it is likely that a balanced and adequate diet for the sheep is under risk and that poor and inadequate feeding may cause chronic stress (13). In addition it was observed that the pastures practically had no canopies and shade and that the herds were usually kept in open areas surrounded by rocks or under trees during the hottest hours of the day. In this situation the sheep were exposed to extreme heat, wind and rain. The pasture which provides an advantage enabling the animals to be removed from the health and welfare risks and allowing them to act in accordance with their ethology is also responsible for some welfare loss risks incurring with the increase of myiasis infections and parasite invasions particularly during periods of excessive heat, difficulty in the observation and 
monitoring of sheep herds under extensive conditions due to the minimal number of shepherds and farmers per herd and as lambs are sent to pasture at an early age (1-2 months) and with the dwindling of human contact dispatching the lambs immediately following return from pasture to slaughter is more stressful compared to lambs which are more accustomed to humans $(1,2,13)$.

Most of the sheep enterprises were operated by the animal owners and family members. Only shepherds were hired externally. The number of personnel employed in the operations was minimal; most of the employees who are entrepreneurs are covered by social security. Most of the employees' educational level is limited to elementary education (averaging 6.10 years). Since only a fraction of the breeders $(8 \%)$ were educated in animal health and breeding and none have been educated in animal welfare it can be concluded that this may have a negative impact on the welfare of the sheep. The reason for this is that it has been reported that human-animal interaction has a significant impact on the behavior, physiology, yield and welfare of farm animals (14). It has been reported that the perception of animal welfare of the employees which are directly in contact with the animals and are responsible for caring, feeding and managing them is related with their educational level while their behaviour towards animals is influenced by the compassion and empathy they feel towards the animals (14). Kellert and Berry (17) has reported that there is a positive relationship between the educational level and attitude towards animals. As the persons responsible for milking and shearing are highly experienced it is concluded that these procedures do not have a negative impact on the welfare of the sheep.

Considering the average number of sheep per herd (198.15 sheep) the number of dogs (2.3) can be deemed adequate. There are very few studies dealing with the direct impact of the dogs used to ensure the safety and management of herds on the welfare of the sheep. From the subject herds of the study it can be concluded that the dogs did not have negative impact on the welfare of the sheep. This conclusion is based on the fact that during the study the herds did not display any signs of fear in terms of the dogs. This may be explained by the fact that the dogs have accompanied the herds for a long time at the same enterprise and the sheep have become accustomed to the dogs. Indeed it has been reported that sheep steered by experienced and well controlled dogs display no signs of stress while inexperienced and out of control dogs inspire fear and panic which causes the sheep to flee and possibly injure themselves (26). The fact that most of the dogs are male may be concluded as the preference of the farmers due to physical conditions valid for bitches such as eustrous, pregnancy and suckling. It has been reported that the gender of herd dogs does not affect their shepherding activities (4).
The study determined that the main target of sheep breeding was for the production of mutton rather than the production of milk or fleece and that the production was extensive. Furthermore, no regular milk yield controls were carried out for the herds. On the other hand, the study revealed that the ratio of difficult deliveries was low while the infertility and aborting rates were high. This is attributed to poor nutrition, housing and hygiene conditions during pregnancy (13). However, as a result of the relatively high multiple birth rate the average lamb yield (1.26) was indicated as being among ideal values (1-1.5 lambs/birth). This situation may be caused by the genetic endowment of the sheep or because some of the breeders release their sheep to forage on the ears which have spilled onto post harvest stubble fields.

The average weaning age (4.16 ay) is compliant with welfare standards $(2,3,5,6)$ and the lambs have been observed to suckle their mothers for long periods. It can be concluded that lamb and sheep welfare is positively affected by the fact that these enterprises target meat production rather than milk production (20). It has been determined that instead of artificial rearing with its negative impact on welfare conditions, lambs are subjected to short term grazing after weaning and slaughtering at the age of 7-8 months.

The study revealed that a very small percentage (3$5 \%$ ) of the studied enterprises cut the ears, tails and horns of the herds. Usually the ears of sheep were cut for numbering while cutting the tails of Purlak lambs with large tails was carried out by using the plastic band method. Some rams had been dehorned when the horns grew to be too long and because the horns compressed the jaw. It is clear that these procedures usually carried out by the farmers have a negative impact on the sheep on an individual level. Modifications such as cutting the ears and tails of sheep (particularly without anesthesia) causes pain, suffering and welfare loss for the sheep (13). However, the health problems due to myiasise and welfare losses of sheep with large tails which have become infected is a reality which must be taken into consideration as well. For this reason although combating myiasise which progresses slowly and may be fatal is painful and causes suffering and loss of welfare, tail cutting operations are generally accepted. In addition, as myiasis may be extensive in many regions in Turkey (16) there is a need to analyze the welfare losses from Myiasis and tail cutting operations particularly for sheep with fatty tails from the perspective of a cost-benefit analysis (13).

Social concerns in terms of animal welfare have been behind the changes made in the legislation governing the animal husbandry sector in Europe. The issue involves changing production systems in such a way that new welfare requirements which will have a direct impact on production costs are complied with. A 
large percentage of consumers have stated that they are willing to pay more to ensure better welfare for animals $(7,19)$. Within this scope, it has been concluded that effort spent to enhance the welfare standards of the sheep breeding enterprises in Afyonkarahisar and educating the local people and enterprise employees on animal welfare will be beneficial from several aspects.

\section{References}

1. Anonymous: Animal Welfare Approved (AWA-2011) Standards for Sheep. Animal Welfare Institute. Washington, USA.

2. Anonymous: Code of Recommendations for the Welfare of Livestock: Sheep. Department for Environment, Food and Rural Affairs (DEFRA-2000). UK Government Department.

3. Anonymous: Instrument for Pre-Accession Rural Development Programme (IPARD-2010). IPARD Projects 2010. Republic of Turkey Ministry of Food, Agriculture and Livestock, Ankara, Turkey.

4. Anonymous: Livestock Guarding Dogs, Protecting Sheep from Predators, United States Department of Agriculture (USDA-1999) Animal and Plant Health Inspection Service, Agriculture Information Bulletin Number 588, Washington, USA.

5. Anonymous: Model Code of Practice for the Welfare of Animals: The Sheep. Primary Industries Ministerial Council (PIMC-2006). Primary Industries Standing Committee Report 89, Australian Department of Agriculture, AU.

6. Anonymous: Welfare Standards for Beef Cattle. Royal Society for the Prevention of Cruelty to Animals (RSPCA2010), West Sussex, UK.

7. Bozkurt Z, Sossidou EN, Kondrad S (2009): Evaluation of the Local Conditions and Personnel Initiatives to Improve Farm Animal Welfare in European Food Production Chain. Atay Basımevi, Afyonkarahisar.

8. Caroprese M, Casamassima D, Rassu SPG, Napolitano F, Sevi A (2009): Monitoring the on-farm welfare of sheep and goats. Ital J Anim Sci, 8, 343-354.

9. Caroprese M (2008): Sheep housing and welfare. Small Ruminant Res, 76, 21-25.

10. Casamassima D, Sevi A, Montemurro O (1993): Effect of light intensity on performance and behaviour of Comisana ewe-lambs intensively reared. Zoot Nutr. Anim. 19, 251-259.

11. Clark JA, McArthur AJ (1994): Thermal exchanges. In, Wathes CM, Charles DR (Eds.): Livestock Housing. s.97122, CAB International, Wallingford.

12. Curtis SE (1983): Environmental Management in Animal Agriculture. Iowa State Press, USA.
13. Dwyer CM, Lawrence AB (2008): Introduction to animal welfare and sheep. Dwyer CM (Ed): The welfare of sheep. s.1-36, Springer Science+Businnes Media B.V.

14. Hemsworth PH, Coleman GJ (2010): Human-Livestock Interactions: The Stockperson and the Productivity and Welfare of Intensively Farmed Animals. $2^{\text {nd }}$ Edition, CAB International, Oxford, UK.

15. Hodgson J (1985): The control of herbage intake in grazing ruminant. P Nutr Soc, 44, 339-346.

16. Kara M, Arslan MÖ (2011): Kuzeydoğu Anadolu'da hayvanlarda ve insanlarda myiasis. Atatürk Üniversitesi Vet Bil Derg, 6, 245-250.

17. Kellert SR, Berry JK (1987): Attitudes, knowledge, and behaviors toward wildlife as affected by gender. WildlifeSociety Bulletin, 15, 363-371.

18. Lia R, Pantone N (2001): Influenza delle infestazioni da strongilidi-gastrointestinali sulla produzione quanti qualitativa del latte negli allevamenti degli ovini condotti con sistemi tradizionali. Standing Seminar on Sheep milk quality, s. 81-91. Foggia, Italy.

19. Maria GA (2006): Public perception of farm animal welfare in Spain. Livest Sci, 103, 250-256.

20. Napolitano F, Cifuni GF, Pacelli C, Riviezzi AM, Girolami A (2002): Effect of artificial rearing on lamb welfare and meat quality. Meat Sci, 60, 307-315.

21. Penning PD, Parsons AJ, Orr RJ, Treacher TT (1991): Intake and behavior response by sheep to changes in sward characteristics under continuous stocking. Grass Forage Sci, 46, 15-28.

22. Sevi A, Casamassima D, Pulina G, Pazzona A (2009): Factors of welfare reduction in dairy sheep and goats. Ital J Anim Sci, 8, 81-101.

23. Sevi A, Massa S, Annicchiarico G, Dell'Aquila S, Muscio A (1999): Effect of stocking density on ewes milk yield and incidence of subclinical mastitis. J Dairy Res, 66, 489-499.

24. Sevi A, Taibi L, Albenzio M, Muscio A, Dell'Aquila S, Napolitano F (2001): Behavioral, adrenal, immune, and productive responses of lactating ewes to regrouping and relocation. J Anim Sci, 79, 1457-1465.

25. Tekerli M (2009): Koyunculukta Refah. In, Bozkurt Z (Ed): Çiftlik Hayvanları Refahı. Atay Basımevi, Afyonkarahisar.

26. Webster J (2006): Animal Welfare: Limping Towards Eden. Oxford, Blackwell Science.

Geliş tarihi: 11.12.2012 / Kabul tarihi: 25.01.2013

\section{Yazıșma adresi:}

Yrd. Doç. Dr. İbrahim Kılıç

Afyon Kocatepe Üniversitesi

Veteriner Fakültesi Biyoistatistik Anabilim Dalı

Ahmet Necdet Sezer Kampusü 03200-Afyonkarahisar e-mail:kilicibrahim@hotmail.com 